\title{
EVALUATION OF RESIDUAL MATERIALS WITH MODEL CONSTRUCTION WASTE MANAGEMENT
}

\author{
Rudi Dwi Asguno, \\ Faculty of Engineering \\ Civil Engineering Program \\ Narotama University, Jl. Arif Rahman Hakim 51 Surabaya \\ rudidwiasguno@gmail.com \\ Diah Ayu Restuti Wulandari \\ Faculty of Engineering \\ Civil Engineering Program \\ Narotama University, Jl. Arif Rahman Hakim 51 Surabaya \\ diah.wulandari@narotama.ac.id
}

\begin{abstract}
In development and renovation of Mawar Sharon Church Surabaya lot of material left over and not used anymore, due to frequent damages to the contractor and the grounds look untidy as the lack of collection points the rest of the material, causing costs to the process of disposal of waste material and cause harm very much. The goal is to determine the potential occurrence of residual material. The method used is the Pareto method for determining the material to be observed in determining the most material waste. By selecting $20 \%$ of the amount of material that has the effect of waste material by $80 \%$. Furthermore, using the calculation of waste levels to find the volume of waste material from the amount of material obtained from the analysis of Pareto, then the calculation of waste index to determine the value of material waste that occurs projected in any $\mathrm{m} 2$, last used method of waste cost to determine whether the waste levels were great also produce waste the greater the cost. Under this method, the remainder of the highest material ie iron material with a value of $34755.13 \mathrm{~kg}$ of waste volume and waste level of $4.76 \%$ with a value of USD 379178441 Cost of waste.
\end{abstract}

Keywords: Remaining Materials, Waste Management, Pareto method.

\section{INTRODUCTION}

Research from (Asad, 2012) which is in the construction industry, the use of materials in the field can cause the rest of the material. The rest of the material is part of the unused material in the implementation of construction projects and not be part of the building. So the more the rest of the material that occurs, the more inefficient use of materials in the project. Alternative-alternatives to mitigate and minimize waste materials, while improving the company's performance began to be felt necessary to do research.

From research (Valentino, 2010) describes the definition of material waste is one of the serious problems in the implementation of construction projects. Efforts to minimize waste materials will help increase the profits of contractors and reduce environmental impact. Therefore it is necessary to do a careful calculation and precise in determining the amount of material needs to be used in the project as well as an evaluation of the use of these materials.

For the definition of (Wulfram, 2012) on sustainable construction as a construction that takes into account aspects of sustainability, namely the use of natural resources that takes into account environmental capacity to prevent environmental degradation. Many factors cause, one of which is inefficient in the construction process. 
To be more focused on the problems that exist, in this study will be given limitations problem as follows:

1. What is the result of the greatest material residual volume and results of waste cost?

2. How do I identify the source of the cause and handling of waste material at the project is executed based on the model of sustainable development?

3. How do I minimize the residual material from appearing again in an ongoing project based on the model of sustainable development?

According Sugiyarto, et al (2017) of waste material in the construction work necessary to plan for the implementation becomes more effective use of the material so that no problems occur due to residual material. The cause of the rest of the material one of the factors of implementation and material handling field.

Meanwhile, according to Conservation, et al (2013) at the implementation stage of construction is often the case of waste material large enough value at the time of use of the material in the field, making an effort to minimize material waste is important to apply. Materials used in construction can be classified into two major parts of consumable material and non-consumable material. Causation and classified into six of the problem in terms of methods, measurement, people, environment, machinery and material.

Research by Asad (2012), namely waste materials will continue to increase with the development of the construction carried out, in addition to affecting the cost of the project, will also create new problems very disturbing the surrounding environment and the project. Controlling the magnitude of the quantity of waste material can be done by finding ways to reuse, recycle, destroy, seek solutions to reduce material waste.

\section{RESEARCH METHODS}

The methods used include the first is the Pareto method for determining the material to be observed and discussed in determining the most material waste. By selecting $20 \%$ of the projected amount of material which has the effect of waste material by $80 \%$.

Furthermore, the latter uses to determine the level of waste the calculation of the volume of waste from the amount of material that has been obtained from analysis of Pareto. Then, the third calculation to determine the value of the index waste material waste that occurs projected in any $\mathrm{m} 2$, and the latter method to determine whether the waste cost a great level waste also generates waste cost that great anyway.

\section{RESULT AND DISCUSSION}

Material unit price to be paid for the purchase of unity kinds of building materials and are used in the Project Development and Renovation Mawar Sharon Church Surabaya.

Table 1. Material Unit price

\begin{tabular}{|c|c|c|r|}
\hline No & Material & Unit & \multicolumn{1}{c|}{ Unit Price } \\
\hline 1 & Iron & $\mathrm{kg}$ & 10.910 \\
\hline 2 & Multiplex & $\mathrm{m} 2$ & 191.320 \\
\hline 3 & Concrete & $\mathrm{m} 3$ & 971.689 \\
\hline 4 & Steel Plate $10 \mathrm{~mm}$ & $\mathrm{~m} 2$ & 22.294 \\
\hline 5 & Concrete Brick & $\mathrm{m} 2$ & 126.670 \\
\hline
\end{tabular}


In identifying the material, the first thing to do is rank Trading Consumable Materials (TCM) based on total costs, resulting in a great get into the first order. Subsequently made columns percent fee then be cumulative resulting column percent of the cost.

How to determine the percent of the cost is the total price divided by the price every material whole material and then multiplied by $100 \%$.

Tabel 2. Column percent of costs created by the form of tables and contains a variety of materials as well as the price and volume of the material itself as follows

\begin{tabular}{|c|c|c|c|c|c|c|c|c|}
\hline No & Material & Unit & Volume & HSPK & Total Price & Cumulative Price & $\%$ Cost & $\begin{array}{l}\text { Cum \% } \\
\text { Costs }\end{array}$ \\
\hline 1 & Iron & $\mathrm{kg}$ & 695102.55 & 10.910 & 7.583.568.821 & 7.583.568.821 & 57.06 & 57.06 \\
\hline 2 & Concrete & $\mathrm{m} 3$ & 3045.22 & 971.689 & 2.959.006.777 & 10.542 .575 .597 & 22.26 & 79.32 \\
\hline 3 & Multiplex & $\mathrm{m} 2$ & 13329.78 & 191.320 & 2.550 .253 .510 & 13.092 .829 .107 & 19.19 & 98.50 \\
\hline 4 & Concrete Brick & $\mathrm{m} 2$ & 1450.29 & 126.670 & 183.708 .234 & 13.276.537.341 & 1.38 & 99.89 \\
\hline 5 & Steel Plate $10 \mathrm{~mm}$ & $\mathrm{~m} 2$ & 675.88 & 22.294 & 15.068 .069 & 13.291 .605 .410 & 0.11 & 100 \\
\hline \multicolumn{5}{|c|}{ Total $=$} & 13.291 .605 .410 & & 100 & \\
\hline
\end{tabular}

The results of the cost calculation of waste material has been obtained from the calculation Trading Consumable Materials (TCM) based on the total price of the value of waste material sorted largest to the smallest.

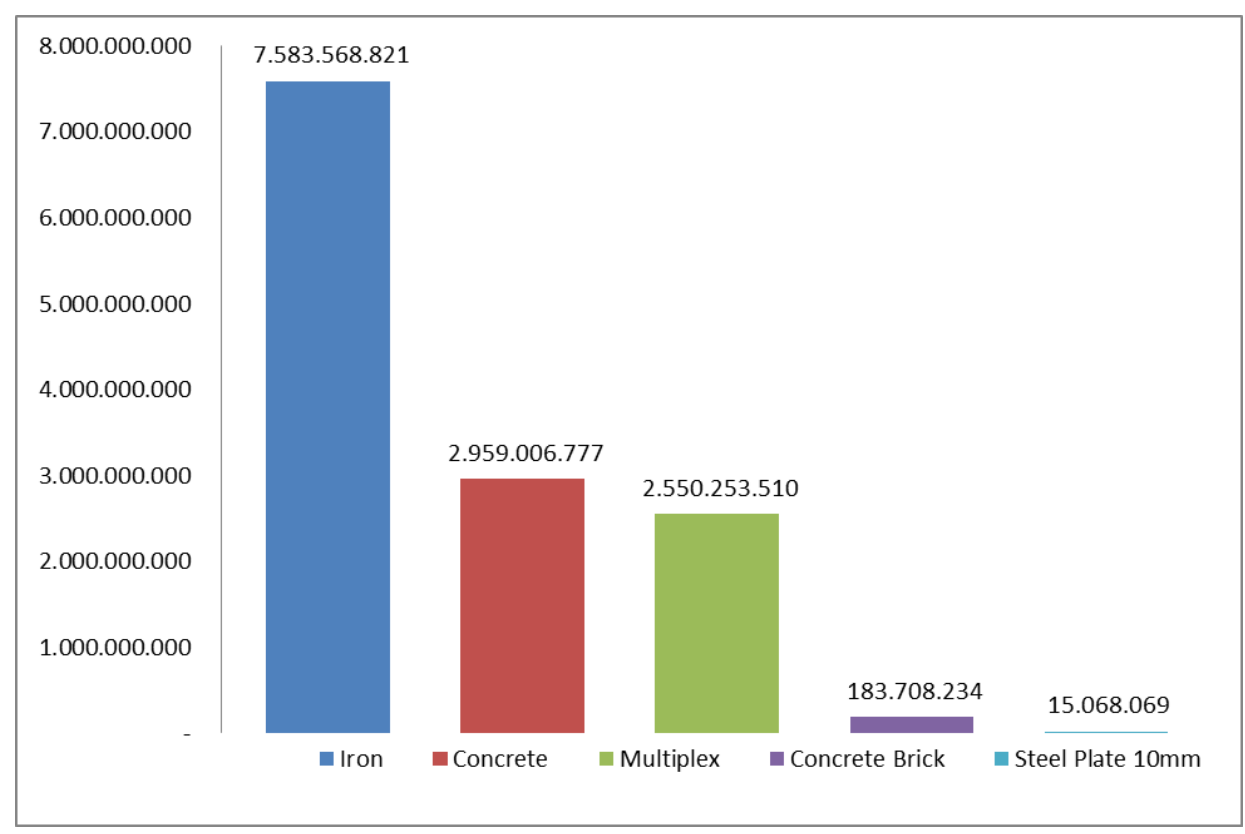

Figure 1. Result of total price

The results of Pareto diagram is part of the left axis shows the cost of waste material while the bottom axis is the type of material studied. The rest of the material selected for 
the study which is $20 \%$ of the overall material. The rest of the construction material that was dominant in construction and renovation projects Mawar Sharon Church In Surabaya taken from the value of the remaining cost of the greatest material ie iron material has a value of $\mathrm{Rp} 7,583,568,821$.

\section{Waste Level}

Level waste calculation to determine the volume of waste from the amount of material that has been obtained from analysis of Pareto. How to determine the volume of waste is on the arrival logistical or material which reduced unused material attached, whereas to determine the outcome of that level waste from waste volume divided by the arrival of logistical or material that is used, then the result is multiplied by 100 . In this calculation, we can know the material potential waste.

Table 3. Perecentage of waste material

\begin{tabular}{|c|c|c|c|c|c|c|}
\hline No & Material & Sat & Logistical Arrival & Installed & $\begin{array}{c}\text { Volume } \\
\text { Waste }\end{array}$ & $\begin{array}{c}\text { Waste Level } \\
(\%)\end{array}$ \\
\hline 1 & Iron & $\mathrm{kg}$ & 729857.68 & 695102.55 & 34755.13 & 4.76 \\
\hline 2 & Concrete & $\mathrm{m} 3$ & 3136.58 & 3045.22 & 91.36 & 2.91 \\
\hline 3 & Multiplex & $\mathrm{m} 2$ & 13729.67 & 13329.78 & 399.89 & 2.91 \\
\hline 4 & Concrete Brick & $\mathrm{m} 2$ & 1493.80 & 1450.29 & 43.51 & 2.91 \\
\hline 5 & Steel Plate 10mm & $\mathrm{m} 2$ & 709.67 & 675.88 & 33.79 & 4.76 \\
\hline
\end{tabular}

In the table above there is a material that has the largest percentage level waste is material iron rods at $34755.13 \mathrm{~kg}$ of waste volume and waste amounted to $4.76 \%$ level. While the percentage of waste materials that have the smallest level of $10 \mathrm{~mm}$ steel plate material with waste volume waste $33.79 \mathrm{~m} 2$ and has a level of $4.76 \%$.

\section{Waste Index}

Waste index value can be obtained from the observation data and interviews with supervisors and implementers in the field. To determine the value of $W$ is the size of the truck and the disposal of waste material every day, while the value of the GFA that of building area. From the data obtained is known that in the construction and renovation project Mawar Sharon Church In Surabaya to dispose of waste material generated at the project site using a truck if it looks very much garbage or waste material. So from the information above calculation approaches:

$$
\begin{aligned}
& \text { Waste Index }=\frac{W}{G F A} \ldots \ldots \ldots \ldots \ldots \ldots \ldots \ldots \ldots \ldots \\
& \text { Waste Index }=\frac{5,5 \mathrm{~m} 3 \times(1 \times 4)}{3467 \mathrm{~m} 2} \\
& \text { Waste Index }=\frac{22}{3467}=0,0064
\end{aligned}
$$


The results of the index value by 0.0064 waste, the value can be understood that in the case of waste material per $\mathrm{m} 2$ of 0.0064 , but the figures above can not conclude whether the management of waste in construction and renovation projects Mawar Sharon Church in Surabaya is good or not so as to stated limitation index waste is good or not good, have to do more research to take into account the cost of waste in order to determine the value of the cost of waste.

\section{Waste Cost}

The calculation of the cost of waste is performed to determine whether a large volume of waste also generates waste cost that great anyway. This is to prove that the material with a large percentage of waste levels also have a large waste cost as well. In addition, the weight of the work was also influential in determining the cost of waste. To find the value of the total weight is divided by the cumulative price every material price. So, if a material that has a weight of work and waste a great level then the value of waste costs will be greater.

Table 4. Waste Material of cost

\begin{tabular}{|c|c|c|c|c|c|c|c|c|c|}
\hline No & Material & $\begin{array}{c}\text { Vol. Material } \\
\text { Terpasang }\end{array}$ & $\begin{array}{c}\text { Vol. Material } \\
\text { Used }\end{array}$ & Vol. Waste & $\begin{array}{c}\text { Waste } \\
\text { Level }\end{array}$ & Unit Price & Total Price & Job Load & Waste Cost \\
\hline 1 & Iron & 695102.55 & 729857.68 & 34755.13 & 4.76 & 10.910 & 7.962 .747 .262 & 0.57 & 379.178 .441 \\
\hline 2 & Concrete & 3045.22 & 3136.58 & 91.36 & 2.91 & 971.689 & 3.047 .776 .980 & 0.22 & 88.770 .203 \\
\hline 3 & Multiplex & 13329.78 & 13729.67 & 399.89 & 2.91 & 191.320 & 2.626 .761 .115 & 0.19 & 76.507 .605 \\
\hline 4 & Concrete Brick & 1450.29 & 1493.80 & 43.51 & 2.91 & 126.670 & 189.219 .481 & 0.01 & 5.511 .247 \\
\hline 5 & Steel Plate 10mm & 675.88 & 709.67 & 33.79 & 4.76 & 22.294 & 15.821 .472 & 0.001 & 753.403 \\
\hline
\end{tabular}

The results of the table can be seen that the waste material that has the greatest cost is the iron rods with a total cost of $\mathrm{Rp} 379178441$ waste While the value that shows the ranking of the largest percentage level waste is material concrete steel with a value amounting to $4.76 \%$ level waste.

Thus proving that the material with a large percentage of waste level also has a large value of waste cost also according to the results of the largest volume of waste material. In addition, the weight of the work was also influential in determining the value of waste cost. So, if a material that has a weight of work and waste a great level then the value of waste costs will be great as well.

In order to suppress the residual material of excessive iron material that has a residual value of material is very high to do with the way that the accuracy of calculation of iron materials for the project were implemented, so that the field can be more attention to the form of calculation when cutting the iron is still new to the rest of the iron can used again in other constructions.

\section{Factors Causes And Residual Materials Handling}

There are several causes of waste materials, namely:

1. Work column structure greatly affect steel reinforcement pieces that must be done equally for the job because of mounting cuttings cuttings column should 
also be considered the high and low elevation previous floor to floor you want to work.

2. Iron material is not used for their design changes the image of planners.

3. Where the project from the previous plan has been calculated on the needs of the material and also the materials are projected, but the change in the design of the structure along with the size of the material, then do play a conversion, then the material is already available in the field used for the fabrication of structural work, the important thing is bigger than plan the initial design.

4. Errors in cutting iron resulting residual material that multiply, mistakes due to not see the standard details of the structure.

5. Cancellations or changes place the cuttings iron foundry work that has been done, so the initial cuttings are cut and eventually lead to the rest of the material.

How to minimize the causes of waste material concrete steel, namely:

1. Their control and accuracy when cutting iron short length calculation.

2. Utilize the residual iron if iron pieces whose dimensions are still able to work you want done.

3. Organize or spruce up the place for the rest of the material in accordance with the dimensions or diameter iron.

4. Rechecking before elicitation material when needed (monitoring).

The solution to utilize waste material concrete steel that has occurred in the construction work that is:

1. Used to give pause at the plate structure commonly called scribble.

2. To complement dipekerjaan unilateral reinforcement of columns and beams.

3. Hold the pipe above the floor plate steel structure at the time would do the job of casting to adjust the elevation of the building floor or relat.

4. Utilizing dimensional short enough iron to hold the beam bottom reinforcement in order not to huddle with other reinforcement.

5. In column installed practically to the armature wall that could tie wall with columns.

\section{CONCLUSIONS}

The conclusion after an evaluation of residual material in construction and renovation projects Mawar Sharon Church In Surabaya, the project is still running with the most remaining material is concrete iron material with a value of $34755.13 \mathrm{~kg}$ of waste volume and waste levels by $4.76 \%$ with a value of USD 379178441 waste cost.

Sources cause of residual material that is due to errors in metal cutting, resulting in residual material from multiplying and iron unused material made place to collect waste material from being mixed with some other metal size.

To minimize material waste by means of their control and accuracy when cutting short length calculation accuracy monitoring iron and iron booking and arrival to the project. And also utilize the residual iron if iron pieces whose dimensions are able to be used for the rest of the material is not increased. As well as iron unused material made place to collect waste material from being mixed with some other metal size. 


\section{REFERENCE}

Abdurrahman, M. Asad. 2012. Analysis And Evaluation of Remaining Materials Building Construction In Low-Rise In Makassar. Journal, Department of Civil Engineering, Faculty of Engineering, Hasanuddin University.

Devia, YP, Unas, SE, Safrianto, RW, Nariswari, W. 2010. Identification Time Construction Materials Meet In Effort Sustainable Building. Journals, Brawijaya University.

Diana, WH, Farida, R., Cahyono, BN 2013. Analysis of Remaining Materials Building Construction In Project Professional Teacher Education, State University of Surabaya. Journal, Institute of Technology Surabaya.

I Gusti Putu, ASP, Dharmayanti, GAPC, Parami Goddess, AA 2018. Waste Material Handling In-Rise Building Construction Projects. Journal of Udayana University.

Ismael, Idzurnida. 2013. Delay in Building Construction Projects Causes And Prevention Measures. Journal of the Institute of Technology Padang.

Kusuma, Valentino Arya. 2010. Evaluation of Remaining Materials In Education Building Project And Laboratory of the Faculty of Medicine Uns 8 Floor Stage 1. Thesis, University of March Surakarta.

Rizky, S., Albani, M. 2018. Analysis of Remaining Material Structural Work On Construction Projects. Journal of the Islamic University of Indonesia in Yogyakarta.

Sitepu1, DP, Syahrizal., Goddess, RA 2011. Construction Material Time Analysis Method Using Fault Tree Analysis. Journal, University of North Sumatra.

Sugiyarto, Widi, H., Indra, TP 2017. Time Analysis and Identification of Construction Materials In the Project Development and Improvement Jalan Solo-Gemolong-Geyer Bts, Kab.Sragen. Journal, March Surakarta University.

Suryanto, I., Ratna, SA, Lie, A. 2005. Analysis and Evaluation Time Construction Materials: Sources Cause, Quantity, and Cost. Journal, Civil Engineering Dimension, Vol. 7, No. 1, 36-45.

Wulfram, IE, Biemo, WS, M. Abduh, Surjamanto. 2012. In the Building Materials Reuse Study of Concepts of Sustainable Construction in Indonesia. Journal of the Institute of Technology Bandung.

Yogi, NW, Ganis, A., M. Court, W., Suharyanto. 2017. Evaluation of Construction Waste In Column Works On Building Construction Projects. Journals, Diponegoro University. 